\title{
The holiday effects in stock returns: a challenge for the textile and clothing industry of India
}

DOI: 10.35530/IT.071.04.1710

\author{
BOLAR SHAKILA \\ PINTO PRAKASH \\ IQBAL THONSE HAWALDAR
}

\author{
CRISTI SPULBAR \\ RAMONA BIRAU
}

\section{ABSTRACT - REZUMAT}

The holiday effects in stock returns: a challenge for the textile and clothing industry of India

This research paper examines the holiday effects presence on the Bombay Stock Exchange (BSE), which is a major Indian stock exchange. Textile and clothing industry in India is one of the most important producers in the world, but also the second exporter of textile and apparels globally. The empirical analysis investigates the impact of holiday effect on the development of textile and clothing industry in India. The holiday effect is one of the most important calendar anomalies identified in the financial markets. The methodological approach includes the non-parametric Mann-Whitney $U$-test used to test the equality of means for different sub-sets. The findings revealed that the mean returns for pre-holiday and post holidays were greater compared to that of remaining days, but the empirical results showed that they were not statistically significant for selected stocks of BSE based on daily stock returns data for Ruby Mills and Mafatlal Industries.

Keywords: textile, clothing, pre-holiday effect, calendar anomaly, abnormal returns, Efficient Market Hypothesis (EMH), non-parametric Mann-Whitney U-test

\section{Influența sărbătorilor legale asupra rentabilității piețelor bursiere: o provocare pentru industria textilă și de îmbrăcăminte din India}

Acest articol de cercetare examinează prezența efectelor generate de sărbătorile legale în cazul Bombay Stock Exchange (BSE), care este principala piață bursieră indiană. Industria textilă și a îmbrăcămintei din India reprezintă unul dintre cei mai importanți producători din lume, dar și al doilea exportator de materiale textile și îmbrăcăminte la nivel global. Analiza empirică investighează impactul efectului de sărbătoare asupra dezvoltării industriei textile și de îmbrăcăminte din India. Efectul sărbătorilor reprezintă una dintre cele mai importante anomalii calendaristice identificate pe piețele financiare. Metodologia de cercetare include testul nonparametric Mann-Whitney $U$ utilizat pentru a testa egalitatea mediilor pentru diferite sub-seturi. Concluziile au relevat că randamentul mediu pentru perioada ante-sărbătoare și post-sărbătoare a fost mai mare în comparație cu cel al zilelor rămase, dar rezultatele empirice nu au fost semnificative statistic pentru indicii sectoriali selectați ai BSE, pe baza randamentelor zilnice pentru Ruby Mills și Mafatlal Industries.

Cuvinte cheie: materiale textile, îmbrăcăminte, efect ante-sărbătoare legală, anomalie calendaristică, rentabilitate anormală, ipoteza pieței eficiente (EMH), testul nonparametric Mann-Whitney $U$

\section{INTRODUCTION}

According to the Ministry of Textiles in India, the textile industry contributes to $7 \%$ of Indian industry output in value terms, $2 \%$ of the country's GDP and to $15 \%$ of India's export earnings with over 45 million people employed. The textiles industry in India is currently estimated at around US\$150 billion, but is expected to reach US $\$ 250$ billion by 2019 . A traditional textile market is an area of high interest and is destined to apparel and accessories, households, furnishings and floor coverings [1]. The textile industry in India has two main pillars: yarn and fibre, and processed fabrics and apparel considering that manmade garments represents the largest contributor to total textile and apparel exports from India [2]. The textile and clothing industry in India includes commodities such as: man-made fibres and filaments, cotton, vegetable textile fibres, rug weaving, textile floor coverings, carpet weaving and others. India is an emerging country, but also a member of the BRICS group which includes Brazil, Russia, India, China and South Africa. Moreover, [3] suggested that textile industry also plays a critical role in terms of output, export and employment in the manufacturing sector of China which is one of the BRICS countries, just like India. The stylized facts that characterize an emerging economy include the existence of pro-cyclical policies, fragile economic and financial structure, a high rate of economic growth based mainly on consumption, vulnerability to foreign currency volatility movements, lower per-capita incomes, lack of fiscal transparency and socio-political instability. Portfolio Systematic patterns exhibited by stock returns at specific times of the day, week or month are known as calendar anomalies or calendar effects. Calendar 
anomaly is a type of market anomalies which contradicts the traditional theory of Efficient Market Hypothesis (EMH).

The classic paradigm of Efficient Market Hypothesis $(E M H)$ was widely accepted since the early 1970 s and is based on three essential pillars such as investor rationality, uncorrelated errors, and the assumption that there are no limits to arbitrage. According to [4] the ideal financial market would be guided by the principle that prices provide accurate signals for resource allocation. Stock market efficiency implies that security prices at any moment "fully reflect" all available information. [5], also known as the father of efficient market hypothesis suggested that: "anomalies are chance results, apparent overreaction to information is about as common as underreaction, and post-event continuation of pre-event abnormal returns is about as frequent as post-event reversal". Efficient market hypothesis promotes the idea that a stock market provides correct pricing, and current prices of securities are close to their fundamental values [6]. The fundamental pillar on which the EMH paradigm relies on suggests that stock market security prices always incorporate and reflect all relevant information [7]. Moreover, in an efficient market, arbitrage opportunities are rather insignificant. In other words, it's not possible to outperform the market over the long-term.

On the other hand, behavioural finance paradigm suggests that investment decision is influenced in a large proportion by psychological and emotional factors. [8] suggested that behavioural finance has two building blocks: limits to arbitrage, which argues that it can be difficult for rational traders to undo the dislocations caused by less rational traders and psychology, which methodizes the categories of deviations from full rationality we might expect to acknowledge. In literature, there are three main forms of efficiency, namely weak, semi-strong and strong forms of market efficiency. Calendar effects, specifically, violate the weak form of efficiency, emphasizing the importance of past patterns and seasonality in estimating future prices [9]. However, recent empirical studies on calendar anomalies or seasonal anomalies revealed that some of the calendar anomalies like day of the week effect, month of the year effect and turn of the month effect seem to have weakened or disappeared over the sample time period (see empirical studies [10-15]). Nevertheless, this empirical study attempts to investigate the existence of holiday effect in Indian stock market.

\section{LITERATURE REVIEW}

In the literature, two main pillars of the holiday effect were identified: a) the pre-holiday effect (the price returns of the days preceding the holidays are considerably different from those in other trading days), and b) the post-holiday effect (the price returns of the days that follow the holidays are considerably different from those in other trading days). Technically, the post-holiday represents at least one day after the holiday. However, the post-holiday effect is rarely identified in recent empirical evidence. The holiday effect is one of the most significant calendar anomalies identified on the financial markets. It is characterized by the fact that abnormally high stock returns are reported on at least one day preceding the holiday. The reason could be the excitement or euphoria of financial investors to buy shares before the holidays [16]. For instance, impediments to trading small, illiquid stocks prevent arbitrage activities from eliminating anomalies [17]. Till date, the studies conducted on holiday effect provided mixed results.

Other researchers [18-23] confirm the presence of holiday effect on international stock markets.

Whereas, several researchers [20, 24-26] concluded that holiday effect had disappeared during the sample period. Moreover, Rufael et al. [27] investigated holiday-effect in Indian stock market specifically Pre, Post-Holiday and weekday's effects based on BSE Sensex and NSE Nifty index returns and concluded that Pre-Holiday shows the good returns among other trading days. Further, it is worth noting that a very limited number of empirical research studies on holiday effect have been conducted on Indian stock markets. Hence, this study would make a sensible contribution to literature on Indian stock market. Moreover, this research paper is also very useful for a better understanding of other international emerging markets with similar behaviour.

The early contribution to holiday effect was made by Merrill [28] who researched Dow Jones Industrial Average from 1897 to 1965 found significantly higher returns on days before and after the public holidays. Other researchers [29-30] found significant stock returns before the US public holidays. Coutts et al. reported the presence of Pre-Holiday effects in the All Gold Index on the Johannesburg Stock Exchange did not exist for the period between 1987 and 1997 [21]. In a study conducted by Chong et al. [31] for the US, UK and Hong Kong markets, it was found that holiday effect seemed to be declined, but only significant in the US market for during the period 1991 to 1997. Moreover Pinto et al. [32] argued that risk anomaly represents a significant kind of anomaly considering it is continual and all-inclusive. Cao et al. [33] analyzed the behaviour of New Zealand stock returns by taking a sample from three major indices over four decades from January 1967 to January 2006. The results of the study indicated that pre-holiday existed in the New Zealand market and interestingly it was found pre-holiday effects were limited to firms in the Small Cap Index, compared to Medium Cap and Large Cap firms. Njeri [34] has identified the presence of holiday effect on stock returns of the Nairobi Securities Exchange based on the sample databases. In addition, Tangjitprom [22] examined the holiday effect in Thailand stock returns and volatility during the period from 1994 to 2009 and discovered the existence of significant high returns and higher volatility during the pre-holiday trading day. The results of the study conducted in the Romanian stock market indicated a post-holiday effect for all the indexes under 
study and a pre-holiday effect only for some of them [35]. Hawaldar et al. [36-37] found that the effect events on stock returns in the Indian stock market are not significant, and market reaction is very slow. Dodd et al. [38] examined the holiday effect in fourteen emerging Central and Eastern European (CEE) markets for a period from January 1991 to December 2010. The authors found in many countries significant pre-holiday and post-holiday returns.

Karim et al. [26] studied the Malaysian stock market for the period between 2001 and 2009 and found that there was no significant difference in the mean returns between pre-holiday period and rest of the period. Alagidede [39] found high and significant for the period between 1997 and 2006 pre-holiday effects in African stock returns. Further evidence of holiday effect was provided by Teng et al. [23] who examined the Taiwan Stock Exchange for the period from 1971 to 2011 . The findings of the study made by Kendirli et al. [40] on the stock returns of Shanghai Stock Exchange (SSE) for a period between 2001 and 2012 indicated that although the calendar anomalies were detected, they were not persistent. Very recently, a study conducted by Kamau [41] in the Nairobi Securities Exchange between 2010 and 2015 found the presence of holiday effect. In the Indian context, Nageswari et al. [42] analysed the S\&P CNX Index for ten years and found the highest but insignificant pre-holiday returns during the study period. Shankar et al. [13] studied the holiday effect in Indian BSE Sensex Indices over some time of 2009 to 2015 and found a significant change in the post-holiday Sensex returns for the study period. Lu et al. [43] investigated the impact of holiday anomaly in the Indian stock market and have empirically confirmed the existence of higher returns on the trading day following a public holiday, compared to regular trading days. As additional research perspective, Kim et al. [44] have empirically identified abnormally high returns on the trading day before holidays in certain main stock markets in the U.S. (NYSE, AMEX, and NASDAQ) but also concluded that the holiday effects in the U.K. and Japanese stock markets are independent of the holiday effect in the U.S. stock market. Moreover, Sasikirono et al. [45] have empirically demonstrated that holiday effect also occurs in Indonesia, where the post-holiday average return four times higher than the average return of other trading day. Moreover, Robins et al. [46] suggested that the holiday effect is statistically significant in the CRSP value-weight stock market portfolio and the low-size stock portfolio in every sub-period from 1926 to 2016 considering that the average stock return on the day before holiday market closings is up to 15 times the average return on all the other days of the year.

The literature review provided a comprehensive framework on holiday effect. A significant part of the previous research studies have demonstrated the presence of holiday effects on selected emerging or developed stock markets. Consequently, the results obtained in this study are consistent with similar empirical research studies.

\section{DATA AND METHODOLOGY}

The textile industry in India is an essential segment and is affected by stock market behaviour and this has multidimensional implications for sustainable economic development. To examine the presence of holiday effect in Indian stock market, the study uses daily closing prices of Ruby Mills and Mafatlal Industries which are major stocks in the textile industry traded in Bombay Stock Exchange for the sample period from January 2010 to December 2019. Over the past decade, the BSE behaviour has been empirically analyzed to identify the present holiday effect. Holidays are those days on which no trading activities are carried on in the Indian stock market.

The holidays that are taken into consideration for empirical analysis are the following: Mahashivratri, Id-EMilad, Good Friday, Dr. Ambedkar Jayanti, Mahavir Jayanti, Holi, Independence Day, Ganesh Chaturthi, Ramzan Id/Gandhi Jayanti, Dasera, Mohurum, Diwali, Bakri-Id, and Christmas. The holidays that occurred on Saturdays on Sundays are not considered for the present empirical study. To test the holiday effect, the daily percentage logarithmic returns for ten years time period are calculated by applying the following equation:

$$
R_{t}=\ln \frac{P_{t}}{P_{t-1}} \times 100
$$

where $R_{t}$ is daily return on the index, In - natural log of underlying market series, $P_{t}$ - closing value of a given index on a specific trading day $(t)$ and $P_{t-1}-$ closing value of a given index on a preceding day $(t-1)$.

To test the pre-holiday effect in select stocks of BSE, the non-parametric Mann-Whitney U-test is used. It is applied when there are two independent samples drawn from the same population. Hence, to test the equality of mean returns between two subsets viz pre-holidays and remaining days and post-holidays and remaining days, Mann Whitney $U$-test is used:

$$
U=n_{1} n_{2}+\frac{n_{2}\left(n_{2}+1\right)}{2}-\sum_{i-n t+1}^{n_{2}} R_{i}
$$

where $U$ is Mann Whitney U-test, $n_{1}$ - sample size one, $n_{2}$ - sample size two, $R_{i}$ - Rank of the sample size.

In order to investigate the holiday effect in select sectoral indices of BSE, the total number of 2,364 trading days is divided into the following main groups:

1. Pre-holidays, i.e. trading days before the holidays. In this category, three subsets have been identified:

(i) one day before a holiday ( $\mathrm{T}-1)$

(ii) two days before the holiday (T-2)

(iii) three days before the holiday ( $\mathrm{T}-3$ )

2. Post-holidays, i.e. trading days after holidays. Here also three subsets are formed, such as:

(i) one day after the holiday $(\mathrm{T}+1)$

(ii) two days after the holiday $(\mathrm{T}+2)$ 
(iii) three days after the holiday $(T+3)$

3. Remaining Days. These include all trading days except one day before holidays ( $T-1)$.

Further, the results are tested by using the following hypotheses.

\section{Hypothesis 1}

$\mathrm{H}_{0}$ - There is no significant difference between mean returns of pre-holidays and that of remaining days in select stocks of BSE.

$H_{1}$ - There is a significant difference between mean returns of pre-holidays and that of remaining days in select stocks of BSE.

\section{Hypothesis 2}

$\mathrm{H}_{0}$ - There is no significant difference between mean returns of post-holidays and that of remaining days in select stocks of BSE

$H_{1}$ - There is a significant difference between mean returns of post-holidays and that of remaining days in select stocks of BSE.

\section{DATA ANALYSIS AND INTERPRETATION}

\section{Ruby Mills}

Tables 1 and 2 exhibit descriptive statistics for the pre-holidays, post-holiday and remaining days in Ruby Mills. As shown in the tables 1 and 2 mean returns of pre-holidays (1.5835) are 29.43 times higher compared to means of remaining days (0.0538) and also the results of Mann-Whitney $U$ test $(p=0.001<0.05)$ confirm that there is significant difference between the mean returns of pre holidays and remaining days in Ruby Mills. The findings are in agreement with the previous literature on holiday effect across the global stock markets.

Further, the mean returns of post holidays $(-2.0142)$ found to be negative compared to the means of remaining days (0.0538) and the results of MannWhitney $U$ test $(p=0.218>0.05)$ also reveal that they are not statistically significant.

To make a comprehensive analysis of holiday effect, the days surrounding holidays are identified and descriptive statistics are calculated for each subset. As observed in table 3, in pre-holidays, the two days before holiday ( $T-2)$ reported greater returns (1.608), three days before the holiday $(T-3)$ showed lowest mean returns $(0.248)$ and the average of pre-holiday returns is 1.15 . Where as in post-holiday returns the
DESCRIPTIVE STATISTICS OF PRE-HOLIDAYS, POST HOLIDAYS AND REMAINING DAYS FOR RUBY MILLS BETWEEN 2010 AND 2019

\begin{tabular}{|c|c|c|c|}
\hline $\begin{array}{c}\text { Period } \\
\text { 2010-2019 }\end{array}$ & $\begin{array}{c}\text { Pre-holidays } \\
\text { (T-1) }\end{array}$ & $\begin{array}{c}\text { Remaining } \\
\text { days }\end{array}$ & $\begin{array}{c}\text { Post } \\
\text { holidays } \\
\text { (T+1) }\end{array}$ \\
\hline $\begin{array}{c}\text { No. of } \\
\text { observations }\end{array}$ & 114 & 2136 & 114 \\
\hline Mean & 1.5835 & 0.0538 & -2.014 \\
\hline Std deviation & 0.205 & 9.372 & 20.781 \\
\hline Minimum & 2.8626 & -17.67 & -76.452 \\
\hline Maximum & 4.0799 & 55.58 & 55.43 \\
\hline Skewness & -0.487 & 3.520 & -0.576 \\
\hline Kurtosis & 2.460 & 14.02 & 2.739 \\
\hline
\end{tabular}

Table 2

\begin{tabular}{|c|c|c|}
\hline \multicolumn{2}{|c|}{ RESULTS OF INDEPENDENT SAMPLE TEST } \\
\hline Sub-sets & $\begin{array}{c}\text { Pre-holidays } \\
(\mathrm{T}-1) \text { \& remaining } \\
\text { days }\end{array}$ & $\begin{array}{c}\text { Post holidays } \\
(\mathrm{T}+1) \text { \& remaining } \\
\text { days }\end{array}$ \\
\hline $\begin{array}{c}\text { Results of } \\
\text { Mann-Whitney } \\
\text { U-test }\end{array}$ & $\begin{array}{c}(\mathrm{Z} \text { value })=-12.29 \\
* \mathrm{p}=0.001(\mathrm{~S})\end{array}$ & $\begin{array}{c}(\mathrm{Z} \text { value })=-1.233 \\
* \mathrm{p}=0.218(\mathrm{NS})\end{array}$ \\
\hline
\end{tabular}

* $0.01=p<0.05$ Significant and

** $0.01<p>0.05$ Not Significant

3 days after the holiday $(T+3)$ reported positive returns $(0.077)$, one day after holidays $(T+1)$ recorded lower returns $(-2.104)$ and the average of postholiday returns is -1.19 , which is considerably lower than average returns of pre-holidays.

\section{Mafatlal Industries}

Table 4 exhibits descriptive statistics for the pre-holidays, post-holiday and remaining days for Mafatlal Industries. As shown in the table 4 mean returns of pre-holidays (1.212) are 1.19 times higher compared to means of remaining days (1.020) but they are not statistically significant as shown in table 5 ( $p=0.086$ $>0.05$ ). Further, in contrast to the previous studies, the mean returns of post holidays (2.47) found to be 2.42 times greater than means of remaining days (1.020) and the results of Mann-Whitney $U$ test as

\begin{tabular}{|c|c|c|c|c|c|c|}
\hline \multicolumn{7}{|c|}{$\begin{array}{c}\text { DESCRIPTIVE STATISTICS OF RETURNS FOR DAYS SURROUNDING HOLIDAYS IN RUBY MILLS } \\
\text { BETWEEN } 2010 \text { AND } 2019\end{array}$} \\
\hline Period 2010-2019 & $(T-3)$ & $(\mathrm{T}-2)$ & $(\mathrm{T}-1)$ & $(T+1)$ & $(T+2)$ & $(T+3)$ \\
\hline No. of observations & 28 & 35 & 114 & 114 & 35 & 28 \\
\hline Mean & 0.248 & 1.608 & 1.584 & -2.014 & -1.548 & 0.077 \\
\hline Std deviation & 29.933 & 25.348 & 0.205 & 20.781 & 24.550 & 33.099 \\
\hline Minimum & -74.5069 & -75.6786 & 2.862 & -76.452 & -73.554 & -73.594 \\
\hline Maximum & 48.5750 & 57.1257 & 4.079 & 55.43 & 51.952 & 45.39 \\
\hline Skewness & 0.683 & -0.300 & -0.487 & -0.576 & -0.505 & 1.236 \\
\hline Kurtosis & 3.405 & 1.683 & 2.460 & 2.739 & 1.640 & 4.891 \\
\hline
\end{tabular}


DESCRIPTIVE STATISTICS OF RETURNS FOR

PRE-HOLIDAYS, POST HOLIDAYS AND REMAINING DAYS FOR MAFATLAL INDUSTRIES DURING 2010-2019

\begin{tabular}{|c|c|c|c|}
\hline $\begin{array}{c}\text { Period } \\
\mathbf{2 0 1 0 - 2 0 1 9}\end{array}$ & $\begin{array}{c}\text { Pre-holidays } \\
\text { (T-1) }\end{array}$ & $\begin{array}{c}\text { Remaining } \\
\text { days }\end{array}$ & $\begin{array}{c}\text { Post } \\
\text { holidays } \\
\text { (T+1) }\end{array}$ \\
\hline $\begin{array}{c}\text { No. of } \\
\text { observations }\end{array}$ & 114 & 2136 & 114 \\
\hline Mean & 1.2123 & 1.0203 & 2.4703 \\
\hline Std deviation & 17.8285 & 3.3466 & 17.679 \\
\hline Minimum & -23.912 & -21.849 & -27.726 \\
\hline Maximum & 71.0721 & 18.2234 & 86.125 \\
\hline Skewness & 1.151 & 0.051 & 2.278 \\
\hline Kurtosis & 4.491 & 4.288 & 9.535 \\
\hline
\end{tabular}

Table 5

RESULTS OF INDEPENDENT SAMPLE TEST

\begin{tabular}{|c|c|c|}
\hline Sub-sets & $\begin{array}{c}\text { Pre-holidays } \\
(\mathrm{T}-1) \text { \& remaining } \\
\text { days }\end{array}$ & $\begin{array}{c}\text { Post holidays } \\
(\mathrm{T}+1) \text { \& remaining } \\
\text { days }\end{array}$ \\
\hline $\begin{array}{c}\text { Results of } \\
\text { Mann-Whitney } \\
\text { U-test }\end{array}$ & $\begin{array}{c}(\mathrm{Z} \text { value })=-1.715 \\
{ }^{*} \mathrm{p}=0.086(\mathrm{NS})\end{array}$ & $\begin{array}{c}(\mathrm{Z} \text { value })=-1.914 \\
\mathrm{p} p=0.015(\mathrm{NS})\end{array}$ \\
\hline
\end{tabular}

Note: ${ }^{*} 0.01<p>0.05$ Not Significant mean returns ( -3.20 and -5.50 respectively) and the average of pre-holiday returns is -2.50 . Where as in post-holiday returns the one day after the holiday $(T+1)$ reported higher returns (2.47), two days after holiday $(T+2)$ recorded negative returns $(-3.56)$ and the average of post-holiday returns is -0.35 , which is better than average returns of pre-holidays.

\section{CONCLUSIONS}

Holiday effect is a kind of calendar anomalies which is less explored in Indian stock market. Using daily stock returns data for Ruby Mills and Mafatlal Industries the current study tested pre-holiday effect and post holiday effect in Indian stock market for the period between 2010 and 2019. The results of the study indicated that in case of Ruby Mills that mean returns of pre-holiday are greater compared to that of remaining days and they are statistically significant. Whereas Mafatlal Industries reported greater but insignificant pre holidays returns during the study period. Further, in respect of both select stocks the mean returns of post holidays found to be greater than that of remaining days and however the test results confirmed that they are not statistically significant. The results of the study nullified the presence of post-holiday effect in both select stocks.

Further, mean returns for the days surrounding holidays are calculated and it was found that Ruby Mills showed higher average of pre-holiday returns as compared to average of post-holiday returns On the

DESCRIPTIVE STATISTICS OF RETURNS FOR DAYS SURROUNDING HOLIDAYS MAFATLAL INDUSTRIES DURING 2010-2019

\begin{tabular}{|c|c|c|c|c|c|c|}
\hline Period 2010-2019 & $\mathbf{( T - 3 )}$ & $\mathbf{( T - 2 )}$ & $\mathbf{( T - 1 )}$ & $\mathbf{( T + 1 )}$ & $\mathbf{( T + 2 )}$ & $\mathbf{( T + 3 )}$ \\
\hline No. of observations & 28 & 35 & 114 & 114 & 35 & 28 \\
\hline Mean & -5.503 & -3.201 & 1.212 & 2.4703 & -3.562 & 0.054 \\
\hline Std deviation & 40.63 & 25.91 & 17.8285 & 17.6797 & 25.289 & 1.502 \\
\hline Minimum & -21.23 & -66.32 & -23.9122 & -27.726 & -4.90 & -4.665 \\
\hline Maximum & 70.24 & 65.06 & 71.0721 & 86.1254 & 45.90 & 5.252 \\
\hline Skewness & -1.201 & -0.091 & 1.151 & 2.278 & -0.743 & -1.696 \\
\hline Kurtosis & 3.839 & 1.727 & 4.491 & 9.535 & 5.781 & 3.60 \\
\hline
\end{tabular}

shown in table 5 ( $p=0.067>0.05)$ confirm that there is no significant difference between the means of post holidays and remaining days in Mafathlal Industries.

As observed in table 6 in pre-holidays, the one day before holiday $(T-1)$ reported greater returns (1.21), whereas two days before holiday ( $\mathrm{T}-2)$ and three days before the holiday $(\mathrm{T}-3)$ reported negative other hand Mafatlal Industries showed differing effects as both the averages reported negative returns. Finally, it could be inferred that the present study could not find significant post-holiday effect whereas the presence pre-holiday effect was evident only in case of Ruby Mills during the study period. Further, the study can be extended to other stocks of Textile Industries traded in Bombay Stock Exchange.

\section{REFERENCES}

[1] Ministry of Textiles, Government of India, Annual Report 2017-2018, Available at: http://texmin.nic.in/documents/ annual-report [Accesed June 2019]

[2] India Brand Equity Foundation, An initiative of the Ministry of Commerce \& Industry, Government of India, Available at: https://www.ibef.org/industry/textiles.aspx [Accesed June 2019] 
[3] Yuan, H., Hong, Y., Zhang, J., Hongzhong Zhao, Zhang, Y., Effects of agglomeration externalities on total factor productivity: evidence from China's Textile Industry, In: Industria Textila, 2017, 68, 6, 474-480, http://doi.org/ 10.35530/IT.068.06.1408

[4] Fama, E., Efficient Capital Markets: a review of theory and empirical work, In: The Journal of Finance, 1970, 25, 2, 383-417

[5] Fama, E., Market efficiency, long-term returns, and behavioural finance, In:Journal of Financial Economics, 1998, 49, 283-306

[6] Fama, E., Random Walks in Stock Market Prices, In: Financial Analysts Journal, 1965

[7] Spulbar, C., Birau, R., Emerging Research on Monetary Policy, Banking, and Financial Markets, In: IGI Global, USA, 2019, 322, http://doi.org/10.4018/978-1-5225-9269-3

[8] Barberis, N., Thaler, R., A survey of behavioural finance, Handbook of the Economics of Finance, Elsevier Science B.V., 2003

[9] Kumar, H., Rachna, J., Efficient Market Hypothesis and Calendar Effects: Empirical Evidences from the Indian Stock Markets, In: Business Analyst, 2017, 37, 2, 145-160

[10] Wong, W. K., Agarwal, A., Wong, N.T., The Disappearing Calendar Anomalies in the Singapore Stock Market, In: The Lahore Journal of Economics, 2006,123-139

[11] Ahsan, A., Sarkar, A., Does January Effect Exist in Bangladesh?, In: International Journal of Business and Management, 2013, 8, 7, 82-89

[12] Gouider, J.J., Kaddour, A., Hmaid, A., Stock Market Anomalies: Case of Calendar Effects on the Tunisian Stock Market, In: Global Journal of Management and Business Research (B), Economics and Commerce, 2015, 15, 2

[13] Shankar, R.G., Kallarackal, T.K., A Study of Holiday Effect on Sensex Returns in the Indian Market, In: International Journal of Research in Finance and Marketing (IJRFM), 2016, 6, 11, 63-68

[14] Shakila, B., Pinto, P., Hawaldar, I.T., Semi-monthly effect in stock returns: new evidence from Bombay, In: Investment Management and Financial Innovations, 2017, 14, 3, 160-172

[15] Hawaldar, I. T., Shakila, Pinto, P., Empirical Testing of Month of the Year Effect on selected commercial banks and Services Sector Companies Listed on Bahrain Bourse, In: International Journal of Economics and Financial Issues, $2017,7,2,426-436$

[16] Marrett, G., Worthington, A., An Empirical note on the holiday effect in the Australlian stock Exchange, In: Applied Economics Letters, 2009, 1769-1772

[17] Fang, L., Lin, C., Shao, Y., School Holidays and Stock Market Seasonality, Financial Management (FM), 2017, 47, 1, 131-157

[18] Arsad, Z., Coutts, J. A., Security price anomalies in the London International Stock Exchange: A 60-year perspective, In: Applied Financial Economics, 1997, 7, 5

[19] Brockman, P., Michayluk, D., The holiday anomaly: An investigation of firm size, In: Quarterly Journal of Business and Economics, 1997, 36, 3, 21-39

[20] Vergin, R. C., McGinnis, J., Revisiting the holiday effect: Is it on holiday?, In: Applied Financial Economics, 1999, 9, 3, 477-482

[21] Coutts, J. A., Sheikh, M. A., The anomalies that aren't there: the weekend, January and pre-holiday effects on the all gold index on the Johannesburg Stock Exchange 1987-1997, In: Applied Financial Economics, 2012, 12, 12, 863-871

[22] Tangjitprom, N., The Calendar Anomalies of Stock Return in Thailand, In: Journal of Modern Accounting and Auditing, 2011, 7, 6, 565-577

[23] Teng, C. C., Liu, V. W., The pre-holiday effect and positive emotion in the Taiwan Stock Market, 1971-2011, In: Investment Analysts Journal, 2013, 42, 77, 35-43

[24] Keef, S. P., Roush, M. L., Day-of-the-week effects in the pre-holiday returns of the Standard and Poor's 500 stock index, In: Applied Financial Economics, 2005, 15, 107-119

[25] Marquering, W.J., Nisser, Toni, Valla., Disappearing anomalies: a dynamic analysis of the persistence of anomalies, In: Applied Financial Economics, 2006, 16,4, 291-302

[26] Karim, B. A., Karim, Z. A., Nee, T. A., Holiday effects in Malysisa: An Empirical Note, In: International Journal of Research in Economics and Business, 2012, 1, 1, 23-26

[27] Rufael, A.G., Prabakaran, V., Stock Market Anomaly: Evidence from Holiday Effect of Indian Stock Market, In: International Journal of Recent Research and Applied Studies, 2017, 4, 2, 1, 1-5

[28] Merrill, A. A., Behaviour of Prices on Wall Street, In: Journal of Finance, 1966

[29] Pettengill, G.N., Holiday Closings and Security Returns, In: The Journal of Financial Research, 1989, 12, 1, 57-67

[30] Ariel, R. A., High Stock Returns Before Holidays: Existence and Evidence on Possible Causes, In: The Journal of Finance, 1990, 45, 5, 1611-1626

[31] Chong, R., Hudson, R., Keasey, K., Littler, K., Pre-holiday Effects: International Evidence on the Decline and Reversal of a Stock Market Anomaly, In: Journal of International Money and Finance, 2005, 24, 7, 1226-1236

[32] Pinto, P., Hawaldar, I.T, Guruprasad, K., Rohit, B., Spulbar, C., Birau, R. \& Stanciu, C.V., The Impact of Risk Anomalies on the Pharmaceutical Sector of the Indian Stock Market - A Comparative Analysis between Pharmaceutical, FMCG and IT companies, In: Revista de Chimie Journal, 2020, 71, 2, 58-63

[33] Cao, X., Premachandra, I. M., Bharba, G. S., Tang, Y. P., Firm size and the pre-holiday effect in New Zealand, In: International Research Journal of Finance and Economics, 2009, 32, 171-187 
[34] Njeri, K. S., The Holiday effect on Stock Returns at the Nairobi Securities Exchange, School of Business, University of Nairobi, Department of Accounting and Finance, 2016

[35] Dumitriu, R., Stefanescu, R., Nistor, C., Holiday Effects on the Romanian Stock Market, 2011, Available at: http://ssrn.com/abstract=2009186 [Accesed June 2019]

[36] Hawaldar, I.T., Thathaiah, M., Indian stock market reaction to the quarterly earnings information, In: Indian Journal of Finance, 2009, 3, 7, 43-50

[37] Hawaldar, I.T., Thathaiah, M., A study of efficiency of the Indian stock market, In: Indian Journal of Finance, 2010, $5,4,32-52$

[38] Dodd, O., Gakhovich, A., The holiday effect in Central and Eastern European financial markets, In: Investment Management and Financial Innovations, 2011, 8, 29-35

[39] Alagidede, P., The month of the Year and Pre-holiday Effects in African Stock Markets, In: SAJEMS, 2013, 64-74

[40] Kendirli, S., Konak, F., Calendar Anomalies in the Shanghai Stock Exchanges, In:Manas Journal of Social Studies, 2014, 3, 3, 77-85

[41] Kamau, J. W., An Assessment of the holiday anomaly in the Nairobi Securities Exchange (Thesis), Strathmore University, 2017, Available at: http://su-plus.strathmore.edu /handle/11071/5592 [Accesed June 2019]

[42] Nageswari, P., Selvam, M., Holiday effects and index returns: Evidences from the Indian stock market, In: International Journal of Business Economics and Management Research, 2012, 3, 4, 49-57

[43] Lu, X., Patel, N., Festivity Anomaly in Indian Stock Market, In: Economics Bulletin, AccessEcon, 2016, 36, 2 , 851-856

[44] Kim, C.W., Park, J., Holiday effects and stock returns: Further evidence, In: Journal of Financial and Quantitative Analysis, 1994, 29, 1, 145-157

[45] Sasikirono, N., Meidiaswati, H., Holiday Effect in the Indonesian Stock Market, In: Advances in Intelligent Systems Research, 2017, 131, 109-112, International Conference of Organizational Innovation (ICOI 2017), Atlantis Press

[46] Robins, R.P., Smith, G.P., On Structural Changes in the Holiday Effect, In: The Journal of Wealth Management Spring, 2019, 21, 4, 98-105, https://doi.org/10.3905/ jwm.2019.21.4.098

\section{Author:}

BOLAR SHAKILA ${ }^{1}$, PINTO PRAKASH ${ }^{1}$, IQBAL THONSE HAWALDAR 2 , CRISTI SPULBAR ${ }^{3}$, RAMONA BIRAU ${ }^{4}$

${ }^{1}$ St. Joseph Engineering College, Vamanjoor, India

email: bolarshakila@gmail.com, prakashpinto74@gmail.com

${ }^{2}$ College of Business Administration, Kingdom University, Bahrain

e-mail: thiqbal34@gmail.com

${ }^{3}$ University of Craiova, Faculty of Economics and Business Administration, 200585, Craiova, Romania

${ }^{4}$ Faculty of Education Science, Law and Public Administration,

Constantin Brancusi University of Targu Jiu, Romania

e-mail: ramona.f.birau@gmail.com

Corresponding author:

CRISTI SPULBAR

e-mail: cristispulbar7@gmail.com 